\title{
International Trade, Social Labelling and Developing Countries : The Case of Bangladesh's Garnments Export and Use of Child Labor
}

Debapriya Bhattacharya

\section{(2) OpenEdition}

\section{Journals}

Electronic version

URL: http://journals.openedition.org/sjep/1359

DOI: 10.4000/sjep.1359

ISSN: 1663-9677

Publisher

Institut de hautes études internationales et du développement

\section{Printed version}

Date of publication: 1 March 1996

Number of pages: $215-238$

ISSN: $1660-5926$

\section{Electronic reference}

Debapriya Bhattacharya, «International Trade, Social Labelling and Developing Countries : The Case of Bangladesh's Garnments Export and Use of Child Labor », Schweizerisches Jahrbuch für

Entwicklungspolitik [Online], 15 | 1996, Online since 18 May 2013, connection on 08 September 2020. URL : http://journals.openedition.org/sjep/1359; DOI : https://doi.org/10.4000/sjep.1359 


\title{
International Trade, Social Labelling and Developing Countries: The Case fo Bangladesh's Garnments Export and Use of Child Labor
}

\author{
Debapriya Bhattacharya
}

Linking of labor standards to trade policy is not a novel idea; yet the recent measures put into effect by the developed countries through "social labelling" of their imports present a new challenge to the post-Uruguay Round multilateral trading system. The heightened debate regarding social dimensions of trade brought to the fore the complex nature of the issue encompassing not only economic but moral aspects as well. The selective deployment of the "social concern driven" trade measures by the industrial countries, however, has given rise to serious doubts about the real intent of these acts. More importantly, there seems to be a consensus among the emerging economies that application of such measures without taking into cognizance the contextual realities may, in the final analysis, turn out to be counter-productive. The present paper, in the example of a new found export niche (readymade garments) of a least developed country (Bangladesh), seeks to illustrate the dilemmas of the choices involved in this respect. Bangladesh's recent experience regarding attempt to eliminate "use of child labor" in the garments sector, in the face of trade boycott threat, is also instructive in highlighting the options available to the actors with ostensibly conflicting interests in the process, viz. the government, workers, entrepreneurs, non-governmental agencies and development partners. 


\section{Global Trading Environment: Cloud Without Rain}

Powerful empirical realities finally brought home to the policy-makers of the developing countries, in the 1980s, the critical contribution of tradable manufactures in structural transformation of their economies. But the "late followers" of export-based strategy encountered not only a severely competitive global economic environment, but also a market place quite enclosed by restrictive trade policies. As the developing countries tried to deal with the domestic supply constraints and related policy failures as well as embarked upon a process of trade liberalization and greater integration with the world markets, the rise of the "new protectionism" in the industrial countries emerged as a matter of major concern. The neo-protectionism of the industrialized countries essentially manifested in erection of non-tariff barriers (NTBs) and practice of non-price measures ${ }^{1}$ which de facto target the laborand resource-intensive products in which the developing countries have a competitive advantage.

Increased use of non-tariff regulations, particularly since late 1970s, became an important feature of trade policy trends of the United States of America (USA), European Community (EC), Australia and Canada ${ }^{2}$. In contrast to the significant upswing in the international trade in the 1980s, persistent and escalated use of non-tariff measures (NTMs) in industrialized countries ${ }^{3}$, inter alia, underwrote further deterioration of the global trading environment for the developing countries as NTMs applied by industrialized countries had a

1. The NTBs include, inter alia, quota fixing, import licensing, voluntary export restraints (VER), special countervailing and anti-dumping duties (CAD). The Multi-Fibre Arrangement (MFA) is one of the most significant non-tariff measures which subjects exports of textiles and clothing from the developing countries to control through bilateral fixing of import quota and their growth rates. Bangladesh happens to be the only least developed country (LDC) which falls under the purview of the MFA.

2. For example, if during 1971-75, the European Community adopted 7 trade monitoring measures against all countries which ended in adoption of a action, the figure rose to 97 by the period 1981-85. In case of the USA, the matching figures were 29 and 152. Between the periods 1971-75 and 1981-85, the number of non-tariff actions taken by EC and USA against LDCs increased by almost 9.5 and 17.5 times respectively (Grilli:1989).

3. Estimate shows that, between 1987 and 1990, NTBs in the developed countries increased by $20 \%$ (UNDP:1992). Calculation based on twelve countries of the European Union and eight other developed countries and covering the period 19811991 , indicated that import coverage ratio (excluding fuel) of the non-tariff measures increased from $16.2 \%$ to $18.3 \%$ (UNCTAD: 1994).

4. In 1992, more than one fifth of non-fuel imports from developing countries (and China) are found to be affected by NTMs, while for trade among developed countries the proportion is estimated to be one tenth. Specific sectors of interest for the developing countries, e.g. textiles, clothing and footwear, showed higher proportion of trade coverage ratios by NTMs in the major OECD markets (UNCTAD op cit). 
greater incidence on their imports from developing countries ${ }^{4}$. In the process, marginalization of the developing countries in the world trading system became most evident in case of the least developed countries (LDCs) as their minuscule share in world export halved during $1980 \mathrm{~s}^{5}$. One of the contributing factors to this relatively poor trade performance of the LDCs had to do with the market access restricting NTMs practised by the industrialized countries ${ }^{6}$.

The non-tariff and para-tariff actions are difficult to oppose through autonomous national initiatives and because of their lack of transparency and selective use they fell in the 'grey areas' of the then General Agreement on Tariffs and Trade (GATT) system. As new types of non-tariff barriers continued to be introduced, the developing countries waited in suspended animation for the successful conclusion of the protracted (1986-1994) Uruguay Round (UR) of multilateral trade negotiations (MTN).

\section{The Uruguay Round Package}

The full implications of the provisions embodied in the Final Act of the UR/MTN for the developing countries in general and LDCs in particular in the areas of market access, agriculture, textiles and clothing, trade related aspects of intellectual property rights (TRIPs), trade related investment measures (TRIMs), multilateral trade rules, and services are yet to be adequately assessed. ${ }^{7}$ Yet, it is well recognized that the overall package of the UR is going to have differential impact on different groups of countries and there is little doubt that the direct and immediate gains arising from the final outcome of the latest MTN will overwhelmingly accrue to the mature industrialized countries and newly industrialized economies (NIEs). ${ }^{8}$ Through out the Uruguay Round of talks the industrialized countries increasingly focussed on the "graduation" issue with a

5. The share of the developing countries in world export declined from $28.3 \%$ in 1980 to $22.6 \%$ in 1991 . During the corresponding period, the share of the LDCs fell from $0.6 \%$ to $0.3 \%$ (UNCTAD: 1993 ).

6. Imports originating in LDCs accounted for only $0.07 \%$ of all non-fuel imports into developed market economy countries in 1984. Despite this insignificant share in total imports of the industrialized countries, NTB affected nearly $15 \%$ of the value of imports originating in LDCs (UNCTAD: 1989).

7. For a succinct summary (in qualitative terms) of the consequences of UR for the LDCs see (UNCTAD: 1995).

8. A number of studies have established this point. See for example (Page: 1992), European Commission: 1994) and (Blackhurst, Enders \& Francois: 1995). An early estimate showed that the developing countries share will be $10 \%$ in the $\$ 250$ bln worth of global welfare gain (excluding service). arising out of the UR package (Nguyen, Perroni \& Wiyle: 1991). A preliminary evaluation by the GATT secretariat in respect of market access indicates that for industrial goods the trade-weighted average tariff reduction by developed countries on products exported by LDCs would amount to $19 \%$ as compared to $32 \%$ for products exported by other developing countries, and 38\% for imports from all sources (cited in UNCTAD:1994). 
view to incorporating restrictions on "special and differential" (S\&D) treatments allowed to the developing countries and insisted on assumptions of such obligations by them which were not acceptable to the industrialized countries even a couple of years back. ${ }^{9}$ Nonetheless, subscribing to a dynamic view, the developing countries went ahead with the negotiated package, with the belief that the Final Act will create a more stable world trading environment and limit the potential for industrialized countries to engage in protectionism and market distortion and, thus, expedite economic progress of the developing countries which are potentially poised to penetrate the global market.

\section{The «new» New Issues}

In the wake of the signing of the Final Act at Marrakesh GATT ministerial conference held in April, 1994, industrialized countries led by the USA and France, in violation of the general understanding, raised a number of "new issues". The most controversial of these was the proposal seeking to establish a link between multilateral trade rights and social issues such as "internationally recognized labor standard practices". Despite their collective view that "the attainment of higher labor standards is fundamentally a matter of debate within each individual sovereign state", the developing countries had to accept that the USA may raise "additional items" including the tradelabor link in discussions in the World Trade Organization's (WTO) Preparatory Committee. ${ }^{10}$

Unfortunately, within less than a year since signing of the "precious agreement", a number of industrialized countries, instead of being guided by the multilateral rules and waiting for the deliberations of the WTO, have initiated an unequal contest of strength with the developing countries by trying to impose social clause in bilateral trading relations." The measures which are being designed by the industrialized countries to influence or counteract the behavior of other countries in labor matter include import prohibitions, levying of countervailing duties, withdrawal of most favored nation (MFN) benefits, charging company penalties, export restrictions and use of bargaining incentives. ${ }^{12} \mathrm{~A}$ number of non-governmental organizations (NGOs)

9. To allay the concerns of LDCs with regard to the overall package, a Ministerial decision was adopted at Marrakesh entitled "Measures in Favor Least Developed Countries".

10. During the Uruguay Round talks, certain industrialized countries also wanted the trade-environment linkage to be recognized in the suggested social clause. Again, as a compromise solution, the Marakkesh Declaration incorporated a provision to set up a new Committee on Trade and Environment. As a related issue, a number of developed countries also sought negotiation of multilateral rules on the competition policy which was also included in the future agenda of WTO.

11. One also observes, in contravention of the dispute settlement mechanism offered by WTO, the use of unilateral trade sanction measures by USA against China and Japan under its "Special 301" provisions of the omnibus 1988 Trade Act. 
joined the campaign to prohibit importation of goods produced in the developing countries with child labor and threatened with boycott. ${ }^{13}$ It is widely held although very difficult to prove that preoccupation with these "trade remedies" to wider socio-economic and somewhat political issues are prompted by the protectionist interests in the industrialized countries.

The sentiment of the developing countries in this context was captured in the declaration adopted by the Conference of Labor Ministers of the Nonaligned Movement (NAM) and other developing countries held in January, 1995, which stated that "we are deeply concerned about the serious postMarrakesh efforts at seeking to establish linkage between international trade and enforcement of labor standards through the imposition of social clause. We wish to reaffirm this position that this linkage is totally unacceptable. At the national level it should be pursued by each country as considered appropriate to its own socio-economic conditions without any form of coercion such as that which the application of social clause may impose - such coercion not only does not conform to the principle of Article 19(3) of the International Labor Organization's (ILO) Constitution and the voluntary character of ILO Conventions but also will negate the benefits which the liberalization of trade is intended to bring about, thus aggravating further at least in the developing countries the existing problems of unemployment and distress. At the international level we believe the right course would be to strengthen the ILO, which is the only competent body for the formulation of labor standards; and to support it, without reservation, in reviewing, updating and consolidating the already established standards" (NAM: 1995a).

The approach above stated position of the developing countries was reiterated in the Communique released after the NAM's Ministerial Meeting of the Coordinating Bureau held in April, 1995. Through the Communique «the Ministers expressed their deep concern with regard to new concepts and proposals which seek to link domestic standards relating to environment, labor laws, human rights, and other social issues, through application of trade measures and bilateral pressures which negate the comparative advantage of developing countries. The Minister's strongly urged all concerned to refrain. from actions which may have the effect of unravelling the carefully negotiated balance of rights, obligations and interests of all parties in the Final Act of the Uruguay Round on the liberalization and expansion of world trade. The NonAligned Movement must remain vigilant by threats posed to the multilateral trading systems via the mechanism of discriminatory restrains, unilateral actions and/or onerous conditionalities" (NAM: 1995b).

12. Introduction of the "Child Labor Deterrence Act of 1993" (better known as Harkin's Bill) in the US Senate epitomized the institutionalization of these measures. We return to this issue later.

13. As we will see later, in case of Bangladesh's garments export it was the Child Labor Coalition and Asia American Free Labor Institutes (AAFLI) which lobbied for the trade boycott. 


\section{Social Labelling: For Whom the Bell Tolls?}

From both economic efficiency and equity considerations, it is well recognized that there is a need to develop and monitor labor standards in order to protect the vulnerable groups, to establish minimum compensation for work, to assure decent working conditions, to ensure workers' collective rights and to provide income security. The fundamental issue, however remains, given the underlying tensions of the recent dynamics of international transactions of commodities, how to design such a public policy for the labor market which would guarantee the desirable labor standards without eroding the short-term welfare gains and long-term growth potential of the developing countries.

\section{Trade-Standard Link}

Initial attempts to associate international fair labor standards (IFLS) with trade policy go back to the discussion on labor treaties in late nineteenth century. ${ }^{14}$ In the recent past, the issue of IFLS was introduced in the Tokyo Round (1973-79) of GATT, but many governments refused to recognize any connection between labor standards and trade policy. The most significant change in international trade covenants respecting labor standards came in 1984, when the Generalized System of Preferences (GSP) was amended to require that developing countries must take steps to meet internationally recognized worker rights in order to retain their eligibility. ${ }^{15}$ It may be noted that the concerned amendment took a phased approach to the labor standard issue and insisted more on declaration of intents on behalf of the exporting countries, rather than on strict enforcement of the respective legislative provisions. At the Preparatory Committee of GATT Uruguay Round, the United States raised the question of "workers rights" in June, 1986 with a view "to ensure that expanded trade benefits all workers in all countries", but the issue was not included subsequently in the agenda for negotiation. As mentioned earlier, USA again tried to reintroduce the theme at the fag end on the UR/MTN to total discomfiture of majority of the negotiating parties.

The current debate on trade-standard links is premised on two major apprehensions. First, disparate labor standards effect terms of trade and inhibits fair competition. Second, low labor standards give rise to negative externalities. Both these concerns need to be viewed in the light of the fact that differences in endowments form the very basis of international trade and low-cost unskilled labor constitutes the main comparative advantage of

14. See, for example, (Charnovitz: 1987) for a histographic account of the issue.

15. These rights included (i) freedom of association, (ii) right to organize and bargain collectively, (iii) a prohibition against forced labor, (iv) a minimum age for child labor, and (v) acceptable conditions of work with regard to minimum wages, hours, safety and health. 
developing countries. Furthermore, use of trade restrictions to alleviate labor conditions may result into unwarranted effects on the precarious poverty and employment situation prevailing in the developing countries. Proponents of 'free trade' emphasize that the concerns of 'fair trade' can be best addressed by sustained incremental income generation, achieved through higher allocative efficiency of resources within a liberal global economic environment.

Responding to the proposition of the international community which advocates that countries which fail to meet a minimum set of labor standards would sooner or later face sanctions in the form of trade restrictions or reduced access to capital, the recent World Development Report pointed out that «linking them (labor standards) to international transaction - trade or financial - raises two complex sets of issues: which standards are basic, and which are a function of the stage of development? And what are the costs of such linkages, both for the economic development of the countries targeted by sanctions and for the workers for whom the sanctions are intended to help? These are important issues, especially since some of the pressure for sanctions comes from protectionist groups" (World Bank: 1995b).

One may, however, seek to conceptually distinguish here between "core standards" and "historical standards" of labor. The former is based on provisions of globally acknowledged human as well as trade union rights including elimination of forced (prison and bonded) labor and discrimination, while the latter constitute of wage and non-wage benefits which are essentially propelled by overall national development. There may be a rationale in using trade sanctions, both on moral and economic grounds, against recalcitrant countries with respect to "basic" labor standards. However, the possibility of "objectively" interpreting evidence of such infractions remains to be hazardous with the prospect of large trading powers getting away with similar misdeeds. But in case of the "historical" standards, trade restrictions, even when well intended, will obviously end up protecting the sun-set activities in retaliating country by discriminating against the cheaper sources of imports as well as by taxing its own consumers.

Understandably, such fine distinctions among labor standards are not easy to draw in real life, not to mention the problems of operationalizing the retribution in cases of labor right infringement through the obtaining global structure of economic governance. ${ }^{16}$ The use of child labor in economic activities in the developing countries happens to be a case in point which epitomizes this dilemma.

16. The failure to impose an embargo on oil import from Nigeria in the face of recent persecution of human right activists in that country illustrates how imperfectly these links are realized given the global realpolitik. 


\section{Child Labor}

The very concept of use of child labor ${ }^{17}$, particularly given its historical correlates, will appear to be universally repulsive. Statistics on child labor are in general fragmentary and suspect. ${ }^{18}$ On the basis of returns from 124 countries, the ILO obtained an acknowledged underestimate of $78.5 \mathrm{mln}$ economically active children under 15 years of age in 1990; $70.9 \mathrm{mln}$ of them were aged 10-14 years, indicating a participation rate of $13.7 \%$ (Ashagrie: 1993). Alternative estimate puts the total number of child workers in the range of $100-200 \mathrm{mln}$, with $95 \%$ of them living in developing countries. ${ }^{19}$

Despite the existence of a wide array of national legislation and international conventions prohibiting or regulating child labor ${ }^{20}$, children remain employed in a great variety of jobs and for many different reasons all over the world. Essentially, children work because they have to; high rates of child labor are undoubtedly linked to poverty and underdevelopment. Applying the analytical framework of welfare economics, it has been argued that "where child labor is a manifestation of poverty, a ban on child labor makes the poor household worse off since it is a restriction of its opportunity set. If, as is quite likely, the ban is not enforced, it will create rents in the system". Concurrently, if the child's welfare depends on his/her cash income, "banning of child labor may leave the child worse off after the intra-household bargaining is completed" (Grootaert and Kanbur: 1995).

17. A distinction may be made between "child labor" and "child work". The former is defined as "work for wages (cash or kind)" and considered to be detrimental for growth and development of children; the latter is considered as "work in the context of household" and is accepted with some degree of ambivalence. Admittedly, this distinction is oversimplified as unpaid work within household can equally interfere in a child's development process, whereas wages earned by the children may enlarge the entitlement basket of the household.

18. The ILO's Convention 138 on Minimum Age of Employment (1993) stipulates that the minimum age of a worker should not be less than the age of compulsory schooling and, in any case, shall not be less than 15 years. Convention 138, however, allows countries whose economy and educational facilities are insufficiently developed to initially specify a minimum age of 14 years and reduce from 13 years to 12 years the minimum age for light work.

19. It will be incorrect to think that child labor use is a malaise which afflicts the developing economies only. According to a study, more than $2 \mathrm{mln}$ children are employed in a number of European countries, particularly in their export oriented industries (e.g. shoe industry of Portugal). The European Community has authorized employment of children 13 years of age leaving employers free to judge possible risks. The study further shows that incidence of child labor is increasing in the United States and infractions of the concerned labor codes increased by $250 \%$ between 1983 and 1990 (The Financial Express, January 4, 1996).

20. Laws setting a minimum age for admission to work and limiting working hours of children who were authorized to work was first enacted in England in 1802, successively followed by Germany (1837), Belgium (1840) and France (1841). 
With a view to address the problem arising out of the gap between prescribed child labor standards and reality, importance has often been attached to labor inspection system and enforcement (ILO: 1992). However, legislative and regulatory approach to child labor "can not deliver desired results unless accompanied by measures to shift incentives away from child labor towards education" (World Bank: 1995a). Thankfully, public policy in the field of child labor is lately undergoing a reorientation along comprehensive and pragmatic lines, where legislation are being complemented by a range of measures covering income and employment generation and, more importantly, by a reform and expansion of education facilities (Bequele and Boyden: 1988).

\section{Veiled Protectionism?}

The labor standard related trade measures espoused by the industrialized countries in the recent years have increasingly focused on banning export items of the developing countries which use child labor. The most notable display of this anxiety relates to introduction of the "Child Labor Deterrence Act of 1993" or the so-called Harkin's Bill in US Congress with the purported purpose of "to curtail the employment of children under age 15 in the production of goods for export by :

1. eliminating the role of the United States in providing a market of foreign products made by underage children;

2. encouraging other nations to join in a ban on trade in such products" (US Senate: 1993). ${ }^{21}$

Concurrently, a group of $\mathrm{NGOs}^{22}$, supposed to be representing the interest of the consumers in the North, launched a vigorous campaign seeking prohibition of import of goods manufactured using child labor. In the backdrop of persistent high rate of unemployment in a number of industrialized countries, an assortment of very influential trade unions (having their origin in the North) also joined the campaign, lobbying for changes in legislation in the countries concerned and inclusion of a Social Clause in international trading agreements. ${ }^{23}$

This recent surge in concern for child labor in the industrialized countries has given rise to a number of legitimate questions.

21. The Foreign Aid Bill of 1993 , forbids US Agency for International Development from assisting any enterprise that uses child labor.

22. These NGOs include Child Labor Coalition, Asian American Free Labor Institute, South Asian Coalition on Child Servitude, etc.

23. These include the International Confederation of Free Trade Unions (ICFTU). 
First, why is the concern for child labor is limited to its use in export oriented manufacturing industry, while incidence of child labor remains more pervasive in other sectors of the developing economies and when working conditions confronted by the child workers outside the export industries are more oppressive and hazardous.

Second, while this circumscribed concern is prima facie based on humanitarian grounds, whether the prime motivation of such policy a stance in prompted by the employment effect of the cheap imports from the developing countries. In fact, Article 9 of Section 2(a) of the Harkin's Bill explicitly states that "adult workers in the United States and other developed countries should not have their jobs imperilled by imports produced by child labor in developing countries".

Third, did not the presently industrialized countries make much more extensive use of bonded labor at the early stage of their development, whereas child labor continues to exist in the developing countries as there are no better options for these children.

Fourth, in their efforts to set better standards in the workplace, why the interested institutions are singling out the case of child labor to the neglect of other labor policy issues, such as, protection to other vulnerable groups including women workers, health and safety measures, minimum wages and trade union rights.

Incidentally, there seems to exist a diversity in the policy approach among the concerned parties with regard to eradication of child labor. For example, Save the Children, a premier international NGO striving for promotion of child rights, reckons that «attempts to ban child labor in some industries are likely to bring even further hardship to many working children and their families" and advocates a "gradualist approach" ${ }^{24}$. On the other hand, the recently adopted four-year (1995-98) scheme of generalized tariff preferences by the $E C$ in respect of certain products originating in developing countries, while indicating the circumstances under which the GSP facilities may be withdrawn mentions only two labor standard related provisions, viz. (i) practice of any form of forced labor as defined in Geneva Convention of 25 September 1926 and 7 September 1956 and international Labor organization Conventions Nos. 29 and 105, and (ii) export of goods made by prison labor. ${ }^{25}$

24. See for details (Poudyal: 1994).

25. See clause 1 of Article 9 under Title III (European Communities: 1994). 


\section{The Readymade Garments Sector in Bangladesh: From Rags to Riches}

Like many other low income developing countries, Bangladesh is also characterized by an economy in transition. Yet, Bangladesh is conspicuous by its presence in the world community because of its stunted development process. ${ }^{26}$ Emergence and growth of the export oriented woven and knitreadymade (RMG) industry in Bangladesh is possibly one of the rare breakthroughs achieved by the country during two and a half decade of its postindependence development efforts. Starting from a modest beginning in early 1980s, within a decade the readymade (RMG) industry in Bangladesh has attained a high importance in the country in terms of its contribution to value added generation, employment expansion and foreign exchange earning. In fact, development of the sector has emerged as a vehicle of social changes in the national context.

\section{Stylized Facts}

Some stylized facts on evolution of Bangladesh's RMG industry can illustrate this phenomenon which unfolded since 1984-85. ${ }^{27}$

- Till the end of 1983, there were only 47 garment manufacturing units in Bangladesh. The number of garments factories shot up to 587 in 1984-85 and by 1992 there were 1051 units operating in the country. According to the Bangladesh Garments Manufacturers and Exporters Association (BGMEA), there are 2224 RMG enterprises currently (September, 1995) in Bangladesh.

- While in 1984-85 less than 10 thousand workers were employed in RMG factories, by 1993 the size of direct employment in the sector was to the tune of 290 thousand. As a result, the share of the industry in formal manufacturing employment increased from $2 \%$ to $15 \%$ during this period.

26. A population of around $114 \mathrm{mln}$, growing at a rate of around $2 \%$ per annum, makes Bangladesh the eighth most populous country in the world. With more than half of the population living below the "poverty line", the country's per capita annual income is only $\$ 224$. The country still remains predominantly agrarian with $85 \%$ of its population living in the rural area and about $36 \%$ of its gross domestic product (GDP) originating from agriculture. The share of manufacturing sector has been stagnating at around $10 \%$ of GDP with about $12 \%$ of the population employed in the sector, the per capita manufacturing value added being only $\$ 12$ per annum. Bangladesh is a classical case for "two gap model»: the ratio of gross investment to GDP is $14 \%$ as against the gross domestic savings of $7.5 \%$, while receipts from merchandise exports can cover up to $60 \%$ of the import bills. Such features of the economy have contributed to an abject external dependence of the country - currently about $\$ 1.8$ $\mathrm{mln}$ is funnelled annually into the country as foreign aid which underwrites more than half of the government's development expenditure.

27. The surge in knitwear exports came later, in 1989-90. 
However, BGMEA claims that the current size of employment in the sector is about 700 thousand.

- It has been estimated that women constitute about $85 \%$ of the labor force employed in RMG units. On the other hand, more than $70 \%$ of female labor force employed in the formal manufacturing sector are located in the RMG enterprises.

- Over the period 1984/85-1993/94, the contribution of the sector to manufacturing value added increased from less than $1 \%$ to about $10 \%$.

- In 1983-84 Bangladesh exported about \$31 mln worth of RMG products which was less than $4 \%$ of the country's total export. In 1984-85, the gross foreign exchange earning from apparel export increased to more than $\$ 115 \mathrm{mln}$, i.e., about $12.5 \%$ of the national export receipts. A decade later, in 1994-95, the country earned a gross amount of about $\$ 1600 \mathrm{mln}$ from wavian and knit-RMG export which constituted about $63 \%$ of total export earnings. ${ }^{28}$

A recent sector study has revealed that the knit and wavian-RMG industry accounted for about $7 \%$ of units, $11 \%$ of fixed assets, $21 \%$ of annual investment, $30 \%$ of employment and wage bill, $23.5 \%$ of gross value added and return on capital attributable in 1992, to the private manufacturing sector in Bangladesh in 1992. Moreover, more than 95\% of the RMG units' and about $90 \%$ of the knitwear units' output were catering to the foreign markets (Bhattacharya: 1995).

\section{Market Access}

The evolution of Bangladesh's apparel export sector bears testimony to the fact that better access to external markets can facilitate the LDCs to get into new lines of manufacturing activities and relaxation of the constraints imposed by small domestic market can allow them to reap economies of scale in production.

Paradoxically, the opportunity for Bangladesh to get into garments export was largely spurred by the MFA. East Asian exporters of RMG to USA and other OECD countries with a view to circumventing their respective country quota, made binding under MFA, entered into various collaborative arrangements with Bangladeshi enterprises regarding supply of their goods. The nascent entrepreneurial class of Bangladesh, taking advantage of a pro-active public policy framework, effectively responded to this window of opportunity. Their entry to the trade was facilitated by the process technology involved in manufacturing RMG, which is relatively simple, labor-intensive and well known in the country.

28. Most of the figures mentioned above have been estimated from data available from official sources, particularly Census of Manufacturing Industries (CMI), 1989-90 and Readymade Garments Industries Survey, 1993. It is maintained, apart from the export figures, all other estimates are on the lower side. 
In 1994-95, destination of Bangladesh's RMG constituted of about 45 countries. However, US market alone accounted for about $52 \%$ of the export value $^{29}$, followed by Germany (more than $11.5 \%$ ), France and Italy $(8.5 \%$ each). In terms of quantity, Bangladesh, currently, is the seventh largest supplier of RMG to the US market, having a market share of more than $3 \%$. For cotton garments, Bangladesh ranks fourth with $5 \%$ of the US market. On the other hand, Bangladesh is the tenth most important source of RMG imports for the EU and Canada.

Concurrently, the limitations imposed on the growth trajectory of Bangladesh's RMG may be, to a large extent, ascribed to the operational pattern of the MFA. Although EU market remains quota free, almost all RMG items exported by Bangladesh to USA are governed by the quota regime. ${ }^{30} \mathrm{~A}$ large number of RMG products imported by Canada from Bangladesh is also subject to quota. ${ }^{31}$ Depending upon type of product, an annual import growth of $6-10 \%$ is usually incorporated in bilateral quota arrangements. Due to Bangladesh's spectacular RMG export performance, the country has achieved quota saturation in a wide range of items, thus inhibiting the possibility of continued growth of the sector. For instance, almost half of the shirt producing factories had to be closed down in mid-1980s due to import restrictions in major markets. Recently, shop towels, of which Bangladesh is the largest supplier to the US market having $15 \%$ market share, have also been subject to quota, a development which is projected to result in a loss of $\$ 30 \mathrm{mln}$ worth of export earnings for Bangladesh (Rahman:1995).

\section{Competitive Advantage}

The current competitive strength of a RMG producing firm in Bangladesh essentially emanates from availability of extremely cheap but usable labor. The significant labor-cost advantage enjoyed by Bangladesh can be seen by looking at the comparative average hourly wages (including fringe benefits) in RMG industry of a number of other developing countries.

For example, while average hourly wages in a Bangladeshi RMG unit is $\$ 0.20$, the corresponding figures for other South Asian countries are the following: Nepal - \$0.25, Pakistan - \$0.40, Sri Lanka - \$0.45 and India - \$0.60. The wage rates in China (\$0.35) and South East Asian countries (Vietnam and Indonesia - $\$ 0.40$, Thailand - $\$ 1.00$ and Malaysia - $\$ 1.20$ ) are much

29. Canada, the other North American market, absorbs a little more than $2 \%$ of the RMG export.

30. However, one-fourth of Bangladesh's export items to US market remain quota free. These include: cotton underwear, baby-wear, gloves and mittens of man-made fibre.

31. Canadian quota are applicable on men's and boy's tailored collar shirts; jackets; trousers, shirts overalls; coveralls; winter outerwear; blouses and shirts; coordinates, athletic sets and sports wear. 
higher than the same in Bangladesh. ${ }^{32}$ Understandably, the prevailing low wages in Bangladesh's RMG sector need to be viewed in terms of labor or total factor productivity. For example, the total person-hours required to produce a shirt of a particular specification in Bangladesh is higher than that of in Sri Lanka or Malaysia. Bangladesh still manages to remain competitive as the wages in most of its competitor countries are increasing at much faster rates.

Nonetheless, the potential for Bangladesh to assert its cheap labor induced competitive advantage is circumscribed by the marginal share (about $12 \%$ ) of labor cost in the cost structure of RMG products. Given that on average $83 \%$ of the total production cost of RMG is attributable to raw material (fabric) costs and since only about $5 \%$ of the fabric consumed in the RMG units are locally produced, it is very difficult for the country to enlarge its competitive edge under the current circumstances (Bhattacharya: forthcoming).

\section{The Current Challenge}

Two particular provisions of the final outcome of the Uruguay Round are going to have significant bearing upon Bangladesh's garments export sector. First, the gradual phasing out of the MFA may affect the country's RMG export to the US market. Second, the gradual erosion of competitive margin provided to Bangladesh's RMG export to EU market under GSP facilities may have adverse consequence. ${ }^{33}$ In other words, almost from the beginning of the next decade, Bangladesh will have to compete with a larger number of established and powerful suppliers of readymade garments in the world market on equal terms.

Obviously, in response to the emerging scenario and in order to retain its competitive edge, Bangladesh will need to, in an accelerated pace, restructure its textile and RMG industries by developing appropriate backward and forward linkages, improve substantially its labor, capital and managerial efficiency, and formulate and implement product and market diversification strategies.

Given its track record and the current policy reform initiatives, Bangladesh will eventually be able to respond to the situation by restructuring the industry, improving productivity and enhancing technological capability. But, subtle nontariff barriers, put into effect in the guise of humanitarian and environmental concerns, may emerge to be more difficult to deal with. The clamor about child labor use in Bangladesh's RMG units signals to be one of such potent non-tariff barriers.

32. The comparable wage rates in Germany, USA, South Korea, Hong Kong, Turkey and Mexico are $\$ 25.00, \$ 16.00, \$ 5.00, \$ 3.90, \$ 3.50$ and $\$ 2.40$, respectively (Financial Express: Nov 10, 1995).

33. Bangladesh's RMG exports to the EU market covered under GSP facilities was $\$ 243$ $\mathrm{mln}$ in 1993-94 accounting for 32\% of total RMG exports outside the markets in USA and Canada. See (Bayes, Hossain and Rahman: 1995). 


\section{Garments Export from Bangladesh: By the Sweat and Toil of Children?}

Till the recent past, the spectre of "child labor issue" was haunting the RMG sector in Bangladesh. Interestingly, while the prospect of official ban on Bangladesh garment exports through legislation in the USA was a factor in triggering the episode, it was US-based NGO lobbyists who were most instrumental in precipitating the crisis. ${ }^{34}$ In order to view the controversy regarding use of child labor in Bangladesh's RMG units in proper perspective, it will be useful to discuss some relevant facts initially.

\section{Incidence of Child Labor}

As per the official definition of civilian labor force in Bangladesh, persons belonging to 10 years and above age group are considered to be part of the working population. The Labor Force Survey (LFS) in Bangladesh, however, provides the number of employed children between 5 to 14 years of age by major occupation categories. Guided by the figures provided in LFS (1989), it has been estimated that about $15 \mathrm{mln}$ children (5-14 years) or about $13 \%$ of the population are economically active in the country. A little more than $82 \%$ of these children are employed in agriculture sector and about $7 \%$ in production and transportation. ${ }^{35}$ For the present discussion, it is important to note that the share of the latter in urban areas, where all the RMG units are located, is to the tune of only $22.5 \%$. However, it is believed that most of these child workers in urban areas are employed in informal and unregulated activities.

The RMG industry is one of the rare formal sector activities where underaged workers are engaged in a sizeable number. Credible figures on number of children working in the RMG sector are difficult to come by. Various observers differ on the precise number: the government officials and the entrepreneurs estimate the share of child garment workers to be $2-5 \%$, whereas local and international NGOs put the figure in the range of $10-20 \%$. In other words, depending upon the source, the estimated number of children working in the Bangladesh garment industry vary between 10,000 and $70,000 .{ }^{36}$

34. Very recently, two Dutch representatives of an international consumer group styled as "Clean Cloth Campaign" had been in Bangladesh to review the wage structure and working environment of the garment workers, see (The Daily Star, November 18, 1995).

35. Agriculture includes livestock, fishery and forestry. Estimate exclusively for the manufacturing (production) sector is not available.

36. For a review of these varying estimates see the Bangladesh Country profile presented in a report on the use of child labor in American imports, prepared for the Committees on Appropriation of the United States Congress (US Department of Labor: 1994). 
A representative sample survey on the conditions of garments workers, carried out in 1991, did not find any worker below the age of 10 years (Chaudhuri and Paul-Mazumder: 1991). However, about $13.2 \%$ of the workers in the sample units were of 10-14 years of age. Accounting for the aggregate employment expansion in the RMG industry between 1991 and 1995 and based on the above mentioned share, we estimate that, in 1994-95, there were about 50,000-55,000 child workers in the sector.

\section{Legal Provisions}

Child labor in the country's RMG sector exists in spite of the fact that a number of laws are in place to protect and improve the status of children in Bangladesh. These legal provisions include Employment of Children Act (1938), the Children (Pledging of Labor) Act (1933), the Bengal Employment of Children Rules (1940), the Factories Act (1968), Tea Plantations Labor Ordinance (1962), the Shops and Establishments Act (1968). However, under the existing laws, the minimum age for employment may be variously interpreted as anywhere between 12 and 16. The National Labor Law Commission, created by the Government of Bangladesh (GOB) in 1993 proposed to eliminate these inconsistencies regarding minimum age of employment by defining a child as a "person who has not completed his/her fourteenth year of age".

The governmental agencies responsible for enforcing child labor laws in Bangladesh, the Department of Labor and Inspectorate of Factories are not adequately equipped with resources to perform the task of monitoring the compliance of relevant legal and regulatory provisions. Absence of a proper birth registration procedure allows the possibility of manipulation of children's age. However, the enforceability of the legal provision regarding child labor needs to be viewed in the broader socio-economic context of the country.

\section{Profile of Child Labor}

The survey mentioned above revealed that the share of children (i.e. between 10-14 years) was higher among female workers (16\%) than among the male workers $(8 \%)$ and the child workers tended to be concentrated in a small segment (19\%) of the sector. ${ }^{37}$ Two-third of the child workers were migrant from rural areas and about $45 \%$ of them were illiterate. Given that girls in the rural areas of Bangladesh are usually married off by the age 14, high incidence $(98 \%)$ of unmarried migrant girl workers suggest a change in social attitude. The presence of a large section of school drop outs among the child workers indicate that the parents could not afford to send them to school. In most cases, a senior member from the child worker's family was found to be

37. It would have been interesting to know whether small enterprises tend to employ more child labor than the big ones. 
working in the same factory. Child workers were by and large engaged as sewing helpers $(66 \%)$ and finishing helpers $(15 \%)$ which were incidentally the lowest paid jobs in the units ${ }^{38}$ (Choudhuri and Paul-Mazumder op.cit).

\section{"The Child Labor Crisis"}

The issue of child labor became a matter of public debate following the introduction of "Child Labor Deterrence Act" in the US Congress in March, 1993. Since the Bangladesh garment industry is overwhelmingly dependent on US market, a US import ban would have had a profound negative impact on the sector. The Child Labor Coalition (CLC), an US based umbrella organization of 40 national NGOs threatened to launch a boycott campaign with effect from July, 1995, unless RMG units in Bangladesh eliminated use of child labor. As certain international NGOs geared up their campaign for boycotting Bangladeshi garments ${ }^{39}$, big US buyers, such as Wal-Mart and K-Mart, put pressure on their local vendors to introduce a "child labor free" labelling system.

The initial official posture of the Government of Bangladesh and the local entrepreneurs was to side-step the issue by denying the existence or down playing the extent of child labor in the RMG units. Conversely, the trade union, human and child rights organizations, without denying the incidence of child labor in the RMG sector, was highly critical about the real intentions of such legislative initiatives and social pressures, describing them as «international conspiracy of the protectionist lobbies ${ }^{40}$. However, once it became apparent that the trade boycott is a real possibility, the Government of Bangladesh, BGMEA, concerned international agencies and NGOs took initiatives to create solutions and seek alternatives for the child workers.

In September, 1993, the BGMEA declared its intention of setting up of schools in cooperation with the ILO, UNICEF and the Ministry of Labor to impart vocational training as well as primary education to the child workers

38. The monthly wages being $\$ 13$ and $\$ 18$ respectively. However, these figures are much higher than the cash incomes received by child workers in other activities in Bangladesh.

39. As a part of its campaign, the Asian-American Free Labor Institute (AAFLI) organized participation of a former garments worker in a hearing before the US Senate Committee on Labor and Human Resources on September 21, 1994. See testimony of Nazma Akhter in (US Senate: 1994).

40. See for example, statement of Srama Bikash Kendra, Ain O Shalish Kendra, Karmajibi Nari Ebong Jatiya Garments Sramik Federation before the press on August 8, 1993 and the pamphlet "Exploding Myths on Child Labour" of Bangladesh Shishu Adhikar Forum. However, similar views were also shared by some members of the Cabinet of Ministers (see The Daily Star, August 2, 1994) as well as by some leading international NGOs (see statement of Oxfam (UK) and Save the Children Fund (UK) representatives in The Daily Star, May 5, 1995). 
engaged in the garment units. ${ }^{41}$ In July, 1994, it was announced that Association inaugurated one small school/clinic for children in Dhaka. ${ }^{42}$ With the child labor issue coming increasingly into both national and international focus, on the same date BGMEA announced that it would eliminate child labor from all garments factories by October 31,1994 . In the face of such a display of cruel indifference by the entrepreneurs, the local NGOs and a number of international agencies particularly ILO and UNICEF expressed their grave concern about the fate of the children to be retrenched.

After a prolonged negotiation which went on during late 1994 and early 1995 between BGMEA and US officials, a draft Memorandum of Understanding (MOU) on elimination of child labor was prepared to be signed by the BGMEA, AAFLI, UNICEF, Centre for Development Research, Bangladesh (CDRB) and the American-Bangladesh Economic Forum (ABEF). However, on May 17, 1995, the Extraordinary General Meeting of the BGMEA rejected the MOU, which was initially agreed upon by its Executive Committee by an overwhelming vote.

As a reaction to the rejection of MOU by the BGMEA members, AAFLI announced that it would, along with Child Labor Coalition, go ahead with the earlier announced campaign for boycott of Bangladeshi RMG in US market and raised questions about BGMEA's good faith during negotiations (AAFLI: 1995a). The BGMEA retorted back by saying that it only helped to prepare the draft MOU, and it has all along held that its signing the accord is subject to the approval by its general members. The major objection of the members of the BGMEA related to the provision which allowed factory inspection by the NGOs. ${ }^{43}$

The BGMEA was soon persuaded to reopen the negotiation for a revised MOU; however, the entrepreneurs' association indicated its preference to work with international agencies such as ILO and UNICEF instead of the NGOs. On May 29, 1995, a consensus was reached on finding an appropriate solution within a revised $\mathrm{MOU}$ at meeting participated by officials of US Embassy, UNICEF, ILO and ABEF. Substantial progress was made on formulating a revised $\mathrm{MOU}$ at follow-up meeting held at UNICEF office on June 3,1995 . In the mean time, AAFLI through a press release rejected the claim that "protectionism" is the underlying motivation for its being concerned about child labor. ${ }^{44}$

41. The Daily Star, September 5, 1993.

42. The Daily Star, July 5, 1994.

43. The Daily Star, May 21, 1995.

44. AAFLI stated that a typical adult garment worker in Bangladesh earns about $\$ 22.50$ per month, while children typically earn roughly $\$ 12.50$. In case of import ban on Bangladesh garments, buyers are not likely to react by shifting the production back to the US where a garment workers make at least $\$ 1,20$ per month. The buyers will most likely go to India, Pakistan, Sri Lanka or Vietnam (AAFLI: 1995b). 
Within a couple of days the negotiating parties - US Embassy, UNICEF, ILO, BGMEA tentatively agreed on a framework for a revised draft MOU which was expected to be finalized at the following meeting which would include representatives from the Government. All negotiating parties agreed on rehabilitation of the retrenched child workers and setting up an independent monitoring mechanism. It was agreed that the monitoring/supervision for the rehabilitation program would be carried out by UNICEF, along with the Ministry of Social Welfare, Women and Children Affairs. ${ }^{45}$ The latest revision suggested to entrust the ILO with the task of monitoring the entire process of elimination and rehabilitation of the child workers. The negotiations also agreed to constitute a steering committee to run the welfare programs.

By June 12, 1995, drafting of a fresh accord was complete, which was to be signed after a meeting with the Government. On June 20, 1995, the Executive Committee of the BGMEA approved the revised draft MOU subject to a few minor clarifications. An inter-ministerial meeting of the GOB held on June 22, 1995, agreed to the draft MOU with some minor amendments in order to make it more effective and to bring it in line with the general stand of the Government.

In response to the world wide sentiment of the importers and consumers of garments regarding the employment of child labor, it was decided unanimously in a special meeting of BGMEA, held on July 23,1995 , to eliminate all child workers from the garments sector by October 31, 1995 under the provisions of the renegotiated MOU. The MOU was finally signed by BGMEA, UNICEF and ILO on August 4, 1995.

\section{Contents of the MOU}

The final agreement on phased elimination of child labor in the Bangladesh garment industry included the following provisions.

i) Child workers below 14 years of age will be removed from the garment factories by October 31, 1995; but no termination will take place without placement of the child workers in an education programs.

ii) UNICEF will initially contribute $\$ 175,000$ in 1995 towards the envisaged education program. The BGMEA will contribute $\$ 50,000$ per year to UNICEF sponsored school program. It is expected that ILO-IPEC Funds will be also made available for the purpose. The program will be arranged in consultation with GOB.

iii) The children under this education program will receive a monthly stipend of Tk. $\mathbf{3 0 0}$ with a view to offsetting, at least partially, the income loss. The BGMEA will contribute $50 \%$ of the cost of such stipends for three years.

45. The Daily Star, June 7, 1995. 
iv) The ILO would monitor the phased child labor elimination program. The process of monitoring the RMG units by ILO will continue for two more years, thus, verifying in a professional manner the implementation of the program.

v) BGMEA will offer employment to qualified family members of the underaged workers whose employment will be terminated under the program.

vi) The survey or rapid assessment of all children working in Bangladesh garment factories will be conducted by 25 survey teams of UNICEF and BGMEA. No child worker will be terminated before the survey is completed.

vii) Efforts will be made to arrange food supplementation program for terminated workers to be placed in schools.

viii)UNICEF and ILO will work towards creating other income generation opportunities after school for the retrenched child workers to occupy their time productively and prevent an income loss.

ix) Registration will be canceled of the owners of the garment units who will continue to employ child labor ignoring the MOU.

\section{Lessons}

It has been maintained that the process of negotiation and the final agreement reached on children working in garment factories in Bangladesh can serve as a model for future reforms in child labor and child rights. ${ }^{46}$ Yet, this very process of negotiation and the final agreement have also exposed the dense interplay of interest of the concerned parties. Certain international NGOs being guided by their stubborn self-righteous stance were bent upon to go ahead with their boycott campaign paying little heed to the economic consequences of their act. Given the total absence of trade union rights in the garment factories in Bangladesh, the workers' representatives could be thoroughly by-passed while their fate was being decided. The associated local NGOs tried to supplant the trade union movement, but at the end of the day they emerged more as a sub-contractor of the implementation mechanism of the agreement. The entrepreneurs demonstrated quite explicitly that in order to protect their narrow self-interest they would have no qualms in getting rid of the child workers. The bilateral agencies while being concerned about the developmental consequences of a trade boycott, were also anxious to ensure that the consumers in their own countries retain the access to cheaper source of imports. The specialized international agencies have possibly felt that, it is becoming increasingly difficult to deal with their mandated activities without getting involved in larger cross-cutting issues.

46. Rolf Carriere. Right Time for a "Rights Approach", in The Daily Star, October 16, 1995. 
Nevertheless, the eventual agreement on the MOU on child workers in Bangladesh clothing industry also revealed that, one can hardly go about dealing with such issues as trade-labor standard links without building an effective alliance between the major stakeholders, viz. the government leaders, private business, development partners and NGOs including the trade unions. The need to protect such a coalition remains all the more relevant in the process of implementation of the agreement.

One may, however, get a feeling that as if the trade boycott threat has worked in cleaning the RMG units in Bangladesh from child labor with a satisfactory backup safety net program. The reality, however, is much more complex. For example, the initial findings of the survey carried out under the provisions of the MOU indicated that there are only 12,305 underaged workers in the garment units. ${ }^{47}$ In fact, immediately after signing of the MOU, the entrepreneurs sacked more than 40,000 child workers in order to limit their involvement in implementation of the MOU. Common sense suggests that many of these retrenched children possibly will possibly have to resort to more hazardous work, begging or prostitution to support themselves. More importantly, keeping the major socio-economic dynamics which forces a child to sell his/her labor in a country like Bangladesh, how can one expect eliminating incidence of child labor even in a part of its economy?

\section{International Trade and Social Labelling: Need for a Phased and Diversified Approach}

The sincere desire of the consumers in the industrialized countries not to be a party in a process which promotes use of child labor is well appreciated. But it needs to be also recognized that without addressing the challenge of poverty alleviation, no bill, ban or boycott can resolve the issue of child labor. It is only presumptuous to think that only external pressure brought about through prohibitive trade controls can enforce child rights in the developing countries. One should rather seek alternatives in a progressive realization of a diversified approach based on a judicious mix of incentives and legislation. Implementation of such an approach will entail revision of allocative priorities (particularly in favor of human resource development) in the developing countries so that the disadvantaged section of the population may effectively engage in gainful activities and gets equitable access to incremental benefits of growth. The global community, of course, can facilitate this process by putting in place an international economic environment which does not inhibit flow of resources to the developing countries through trade and investment. In the short run, to address the concerns of violation of "core labor standards", it is possible to work out a transition program (having no illusion about its limited efficacy), prompted by enlightened self-interest and underwritten by shared responsibility of the major stakeholders.

47. The Daily Star, November 16, 1995. 


\section{REFERENCES}

AAFLI 1995a. Press Release on BGMEA's Rejection of Child Labor MOU, Dhaka, May 20, 1995.

AAFLI 1995b. Press Release on BGMEA's Rejection of Child Labor MOU, Dhaka, May 25, 1995.

Ashagrie, K 1993. "Statistics on Child Labor: A Brief Report" in Bulletin of Labor Statistics, № 3, Geneva.

Bangladesh Sishu Adhikar Forum (undated). Exploding Myths on Child Labour, Dhaka. Bhattacharya, Debapriya (forthcoming). Technological Capability and Export Competitiveness of Bangladesh's Garments Industry, Bangladesh Institute of Development Studies, Dhaka.

Bhattacharya, Debapriya 1995. Manufacturing Sector in Bangladesh. An Aggregate Level Analysis in Structure and Performance of Bangladesh Manufacturing-extrapolated Results of a Stratified Sample Survey of 1992 Data, The World Bank and USAID, Dhaka.

Bayes, Abdul; Hossain, M Ismail \& Rahman, Mustafizur 1995. Trends in External Sector: Trade and Aid, in Experiences with Economic Reform: A Review of Bangladesh's Development 1995, Centre for Policy Dialogue and University Press Limited, Dhaka.

Bequele, Assefa and Boyden Jo 1988. Working Children: Current Trends and Policy Responses, International Labor Review, Vol.127, №.2.

Blackhurst, Richard; Enders, Alice and Francois, Joseph 1995. The Uruguay Round and Market Access: Opportunities and Challenges for Developing Countries. Paper Presented at the World Bank Conference on the Uruguay Round and Developing Economies, Washington DC, January 26-27, 1995.

Chaudhuri, Salma and Paul-Mazumder, Pratima 1991. The Conditions of Garments Workers in Bangladesh - An Appraisal. BIDS, Dhaka.

Charnovitz, Steve 1987. The Influence of International Labor Standards on the World Trading Regime. A Historical Overview, International Labor Review, Vol.126, № 5.

European Commission 1994. GATT and Trade With Developing Countries, Brussels.

European Communities 1994. Official Journal of the European Communities L 348 Vol.37, December 31, 1994.

Garments Katha (News), Dhaka, Various Volumes.

Government of Bangladesh 1994. Readymade Garments Industries Survey Report 1993, Dhaka.

Government of Bangladesh 1995a. Report on Census of Manufacturing Industries, 1989-90, Dhaka.

Government of Bangladesh 1995b. Report on Labour Force Survey, 1989, Dhaka.

Grootaert, Christiaan and Kanbur, Ravi 1995. Child Labor: An Economic Perspective, International Labor Review, Vol.134, No.2.

Grilli, Enzo 1989. Responses of Developing Countries to Trade Protectionism in Industrial Countries, Ld'A-QEH Development Studies Working Paper No. 11, Oxford.

ILO 1992. Labor Inspection and Child Labor, Labor Administration Branch, Document № 31 , Geneva.

Memorandum of Understanding (MOU) between US Embassy in Bangladesh, ILO Bangladesh, UCEP Bangladesh and GSS. Regarding Implementation of a Program to Provide Education to Working Children and to Achieve the Phased Elimination of Child Labor in the Bangladesh Garments Industry, April, 1995. 
Memorandum of Understanding (MOU) between BGMEA, UNICEF and ILO Bangladesh Regarding The Placement of Child Workers in School Programmes and the Elimination of Child Labor, Dhaka, July 4, 1995.

NAM 1995a. Declaration of the Fifth Conference of Labor Ministers of the Non-Aligned Movement and Other Developing Countries, January 19-27, 1995, New Delhi.

NAM 1995b. Communique of Non-Aligned Movement's Ministerial Meeting of the Coordinating Bureau, April 25-27, 1995, Bandung.

Nguyen T, Perroni C \& Wiyle R, 1991. "The Value of Uruguay Round Success", in The World Economy, Vol. 14 (Dec).

Page, $S$ et al 1992. The GATT Uruguay Round Effects on Developing Countries, ODI Special Report, London.

Press Statement by Sramo Bikash Kendra, Ain O Shalish Kendra, Karmajibi Nari O Jatiyo Garments Sramik Federation on Harkin's Bill, Dhaka, August 8, 1993.

Poudyal, Ranjan 1994. International Efforts to Ban Products that Use Child Labor in South Asia, Save the Children (UK), Kathmandu.

Rahman, Mustafizur 1995. The GATT Uruguay Round Multilateral Accord: Implications for Bangladesh, in Bangladesh: Strategies for Development (ed. by Roy H Grieve and Mozammel Huq), University Press Ltd. Dhaka.

Srama Bikash Kendra, Ain O Shalish Kendra, Karmajibi Nari Ebong Jatiya Garments Sramik Federation.Press Statement on Harkin's Bill and Child Rights, Dhaka, August 8, 1995

World Bank 1995a. Jobs, Poverty and Working Conditions in South Asia. Regional Perspective on World Development Report 1995, Washington DC.

World Bank 1995b. Workers in an Integrating World. World Development Report 1995, Washington DC.

The Daily Star, Dhaka, Various issues.

The Financial Express, Dhaka, Various issues.

UNCTAD 1989. The Least Developed Countries 1988 Report, New York.

UNCTAD 1993. Trade and Development Report, 1994, New York and Geneva.

UNCTAD 1994. Trade and Development Report, 1994, New York and Geneva.

UNCTAD 1995. The Least Developed Countries 1995 Report, Mid-Term Review of the Programme of Action. New York.

UNDP 1992. Human Development Report, New York.

US Department of Labor 1994. By the Sweat and Toil of Children: The Use of Child Labor in American Imports, Washington D.C. (mimeo).

US Senate 1993. Child Labor Deterrence Act of 1993. A Bill (S. 613). March 18, 1993, Washington DC (mimeo).

US Senate 1994. Child Labors and the New Global Market Place: Reaping Profits at the Expense of Children? Hearing Before the US Senate Committee on Labor and Human Resources, Sub-committee on Labor, September 21, 1994, Washington DC (mimeo). 


\section{List of Abbreviations}
AAFLI $=$ Asia American Free Labor Institutes
BGMEA = Bangladesh Garments Manufacturers \& Exporters Association
bln = billion
CAD = Countervailing \& anti-dumping duties
CDRB = Centre for Development Research, Bangladesh
CLC = Child Labor Coalition
$\mathrm{CMI}=$ Census of Manufacturing Industries
EC = European Community
EU = European Union
GATT = General Agreement on Tariffs and Trade
GOB = Government of Bangladesh
GSP $\quad=$ Generalized System of Preferences
ICFTU = International Confederation of Free Trade Unions
IFLS = International Fair Labor Standards
ILO = International Labor Organization
LDC = Least Developed Countries
LFS $\quad=$ Labor Force Survey
MFA $=$ Multi-Fibre Arrangement
MFN $=$ Most Favored Nation
$\mathrm{mln} \quad=$ million
MOU = Memorandum of Understanding
MTN $=$ Multilateral Trade Negotiations
NAM = Non-aligned Movement
NGOs = Non-governmental Organizations
NIES $\quad=$ Newly Industrialized Economics
NTBs $\quad=$ Non-tariff barriers
NTM = Non-tariff measures
RMG = Readymade Garments Industry
$S \& D=$ Special and Differential
TRIPs = Trade Related Aspects of Intellectual Property Rights
UNCTAD = United Nations Conference on Trade and Development
UNICEF = United Nations International Children's Emergency Fund
UR $\quad=$ Uruguay Round
USA $\quad=$ United States of America
VER $\quad=$ Voluntary export restraints
WTO $=$ World Trade Organization 